\title{
UNITARY RESPONSES TO SOUND STIMULATION RECORDED FROM THE CEREBELLAR CORTEX OF THE CAT.
}

By

\author{
TADASHI KAWASAKI
}

From the Department of Oto-Rhino-Laryngolgy, Niigata University School of Medicine (Chief: Prof. M. Morimoto, M.D.)

The Brain Research Institute, Niigata University School of Medicine. (Director: Assist. Prof. N. Maruyama, M.D.)

Unitary responses to sound stimulation obtained from the cerebellar cortex were investigated in cats.

Results obtained are as follows:

1) Under barbiturate anesthesia, 2 out of 75 units responded to the sound stimulation, while in curraized cats 23 out of 100 units responded.

2) Two types of response were recorded. One was a response to the onset of the stimulation, "on response", and the other was a response during the stimulation, "continuos response".

3) In some units which showed "continuos response", the number of spikes responding to tone bursts of constant intensity increased and decreased in a $2 \sim 10$ second cycle.

4) Curves of threshold in db S.P.L. versus frequency were made from the responses of 11 units. The threshold curves extended over a wide frequency range and were at high intensity levels of 70 80db S.P.L. and did not show well-defined characteristic frequencies with one exception.

The exception showed relatively low thresholds and the threshold at its characteristic frequency, 9,000c.p.s., was $20 \mathrm{db}$ S.P.L.

5) At some frequencies some units responded to strong stimulation and did not show any response to weaker stimulation, but still weaker stimulation caused responses again.

\section{音刺戟に対する猫の小脳ニユーロン の反応について}

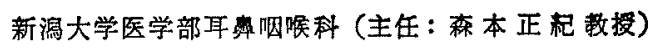
新渴大学医学部譄研然所（指導：丸山直助教授）

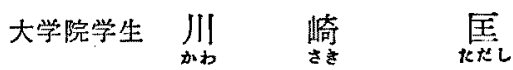

\section{緒言}

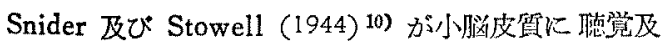
び視覚の受容領野の存することを誘発電位をもつて明ら がして以来, Bonnet 及び Bremer (1951)1), Whitlock (1952) ${ }^{\text {12) }}$, 志村 $(1955)^{13}$ 等がこの領野の标在を確 認した。 しかし小船ニューロンについて unitary activity を検したものとしては Bremer 及び Gernandt

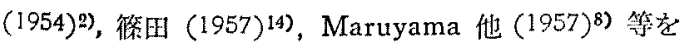

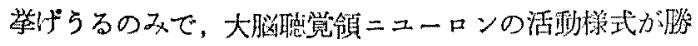

木等の砳究によつて既にかなり鮮明にされているのに比

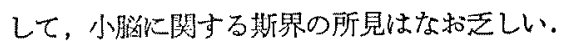

镍田は小脳の聴性反応を示す unitary activity を誘

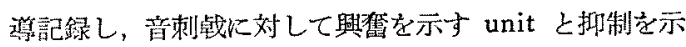
す unitを钼察した。 unitary response の間值が高い こと，単純な反応型式を示すこと等の理由から，誘発電 位の結果をも併せ考劣て，衈性運秒反射に関係与るもの であるらとして，志村の見解を支持した。

者者は小腷の戦一神程活動電位の記録力法を改良し, 
反応 unit の応答野を得たので，篠田の所見に補遗せん とするものである。

\section{実験方法}

実験動物としては，体重 $2.5 \sim 3.5 \mathrm{~kg}$ の成猫を用いた. 一般に超微小電極を用いる契験では，兴の乎吸性並びに

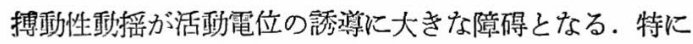
小脳ではこの動摇が著しい，著者はこの点を特に留意 し，改良を施した。

\section{A）麻酔}

麻酔唷の中枢神経娆能に及ばす影響を考临し，2 種頪 の実験を行つた。

（1）オルトパンソーダ (大日本製薬) $0.1 \mathrm{~g} / \mathrm{kg}$ の腹腔 内注射

（2）アメリゾール(吉富製某) $1 \mathrm{mg} / \mathrm{kg}$ の筋肉内注射 の2つである.

\section{B）手術}

上記 (1)，(2) いずれの場合も実験方法としては大差 ないが，(2) の場合，人工呼吸下で実駩孛行つた，手術 は次の順序で行った。

i）気管カニユーレ插入

ii）股静脈切開，ビニールチニーブ插入

iii）小脳露呈，動物を腹位に固定し，頭蓋骨を露呈 し, 紫科用 bar を用いて, 後頭稜の直前正中部直径 約 $1 \mathrm{~cm}$ の穴をあけ, 小脳の一部を露出した.

C) 固 定

固定器としては Horsley-Clark 改良型を使用した. 但し 㯖覚实験であるため耳孔を塞ぐことができないの

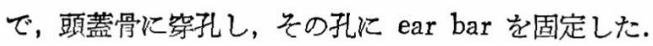

D） chambar の作製

小脳の一部が露呈 している穴の 周囲の頭蓋骨上に resin セメント (松風陶画製) で杯状の堤防を作り， resin が重合した後，硬脸膜を切除した，炊に，厚さ約 $0.8 \mathrm{~mm}$ の透明なアクリル板で直径約 $1.5 \mathrm{~cm}$ の円板をあ らかじめ作製し，中心部に直径約 $1.5 \mathrm{~mm}$ の小孔をあけ て扰く.このアクリル円板で, 先に resin で作つた杯状 の堤防の上飞蓋をし，小孔のある中心部を残してアクリ ル板の周四を'resin セメントで堤防に密着固定した. 頭 蓋骨の小孔上には resin セメントの堤防とアクリル板と で一つの chambar ができたわけである. 小脳露呈部位 は透明なアクリル板を透して明視下に打くことができ る. chambar 内にリンゲル液を充し，気泡を完全に追 い出した後，同じ小孔上り电極を小脑に刺入し，小孔と 電極との僅かの間隙をアルジェックスにて充鎮密䦥し
た.かくして一度開いた頭蓋骨を再び完全に閉じる

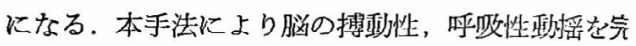
抑光, 一段と生理的な条件下で安定した単一神経細 活動電位を記録することができる.

動物の全身状態を良好に維持するために，常に酧 吸入させ, 保温に注意し, 室内温度を $25^{\circ} \mathrm{C} \sim 30^{\circ}$ 保持した. 又必要に応じて補液を行った。

E) 記録方法

增幅微測淩置は，今日微小電極のために一般に厈 れているものに準じた，前置增幅器としては $12 \mathrm{~A}$ cathod follower を用い, 主增幅器は ADB 增幅器 本光電工業）を使用し， 2 光軸オッシロスコープ( 光電工業 VC6 型) で観察した。一軸㑛刺激音波北 他軸に unitary activity を導入した。使用した電 3M. KCL をつめたガラス毛細管で，3M. KCL 旉 の抵抗值が $20 \mathrm{M} \Omega$ 前後のものを用いた.

F）音刺激装置

音刺激としては tone pip を用い，音源は発振器 河電機製作所）の正弦波を，電子スイッチ（共倠 製)によりスピーカーが追随できる適当な立上り時

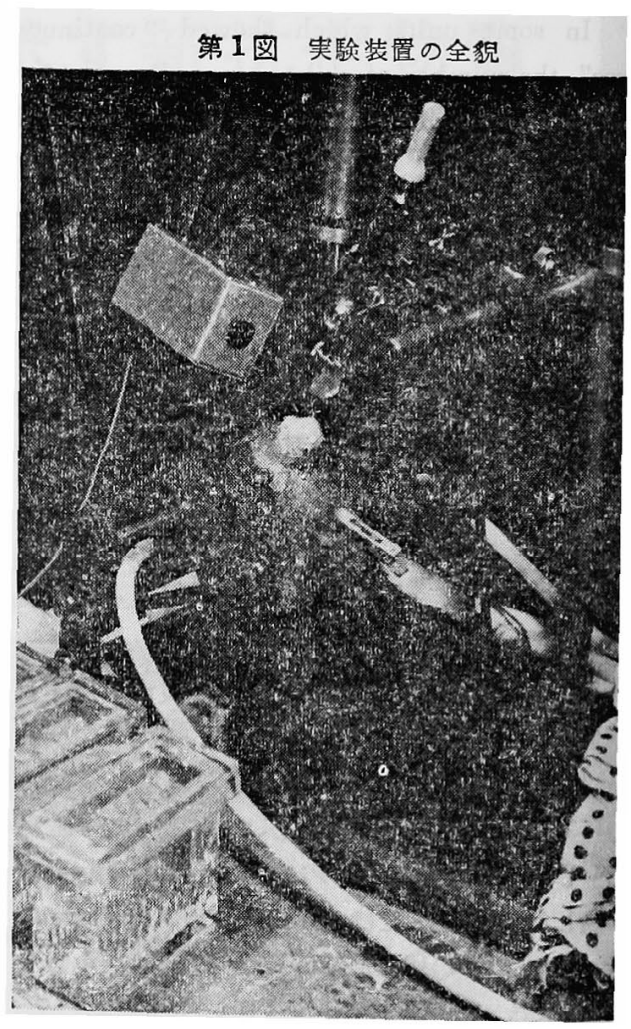


開閉し，スピーカーに導いた、スピーカーは加藤音 響研究所製の tweater を使用した. スピーカーよ り出た音を猫の 頭上につるしたコンデンサー・マ イクロフオンで受けて (MR 103 型), ブラウン管 オッシロスコープに再現し，目っ $1000 \mathrm{cps}$ の標潐 音王により各周波数の sound pressure level (db S.P.L.) を決定した.

\section{実 験 結 果}

総数 175 の unitary activity を観察した. オル トパンソーダの腹腔内注射による麻酔下で, 音響刺

熊 战に反応を示したのは, 75unit 中僅か 2unit であ つた. これに反し,アメリゾールの腹肉内注射，人

韵 工呼吸下で行つた実験では，100unit 中 23unit が

は音響性反応を示した。

(0) 音刺钱に反応を示す unitary activity を誘導記 録した部位の小脳皮質上分布を第 2 図に示した。 そ の分布は Lobus anterior, Lobus simplex, Decli-

䍌 ve, Tuber vermis にわたつている.

音響性反応を示した 25 unit 中, 刺㦸音の立ち上 此りの位置に放電の増加したもの（on 型，第 5 図, 第8 図) 13unit, 音刺㦸中連続して 放電の 增加を 示したもの（連続反応型，第 3 図）

12unit であつた. on 型の反応を示 した 12unit 中, 試みたすべての音 刺㦸に対して on の位置にのみ反応 を示すすは，僅か 4unit で, 他 は試みた刺战のらち一部の刺㦸に対 しては，連続反応型の傾向を示す場 合があつた. 潜時は 5〜20msec に および一定ではなかつた。

調べ得た 11 の応答野中 8 つ応 答野はオッシロスコープ上の観察絬 果から作製され，他は後述の如く， フイルム上の記録をむ参照して作製 された.

観察中しばしば同じ強さの音刺㦸 に対してむ反応放電数が，時間的に 著名な 動摇を示し（第3 図）， 反応 闒値の判定に障碍となつた．自発放 電あるいは損傷電流む時に音刺战に 恰も同期するかの如き錯覚を与え， 放電增加の少い反応と誤られ易く， 又逆に事実反応がある場合でも放篦

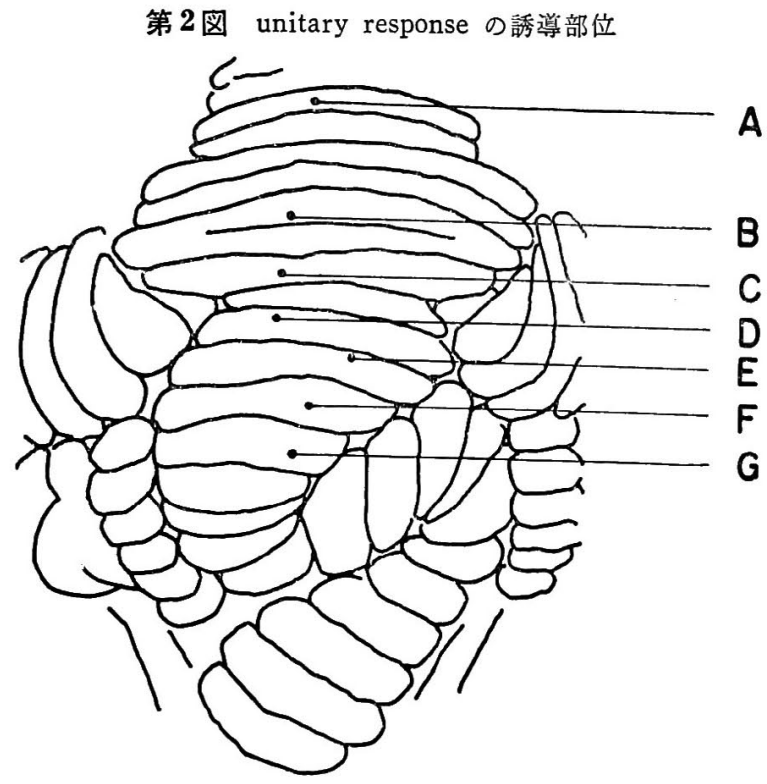

音刺载に反応した 25unit のうち，A 点より lunit, B 点 より 1 unit, C 点より 3unit, D 点より 5unit, E 点より 3unit, $F$ 点より 6unit, $G$ 点より 6unit 記録された。

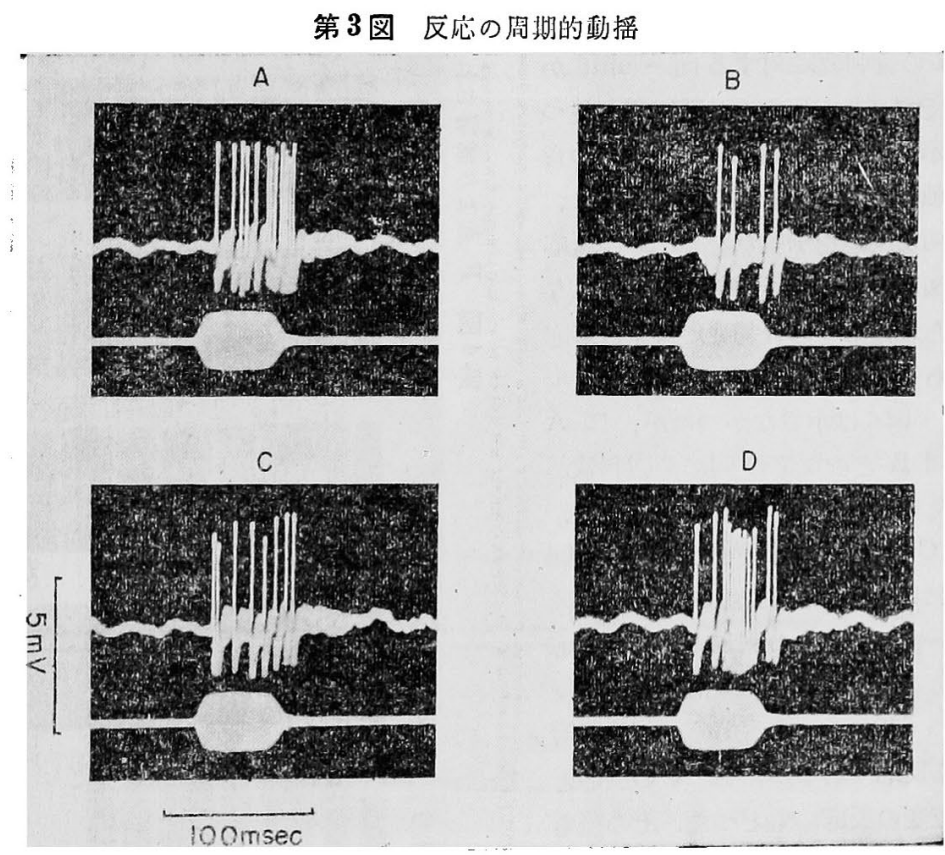


增加の少い反応は自発放電と誤られ 易い。

そこで各周波数につき， $5 \mathrm{db}$ ステ ップで各 10 回の 音刺㦸に 対する反 応を記録して, spike の位置を dot で表わした (dot pattern). 更に 10 $\mathrm{msec}$ 敏淿時䦌軸を分割乙，各区間 に認められる dot の総数をヒスト グラムで表わし, 10 回の音刺㦸分 のデーターを一括総合的に判断でき るようにした，反応閔值はヒストグ ラムから判定した. 従つてオッシロ スコープ上の钼察のみで閾値を判定 乙, unitary spike を dot 乙得な かつたものでは，その閔値は多少正 確を欠くものと思われる.

第 3 図は $\mathrm{E}$ 点(第 2 図)より演 導記録された unitary activity で ある.この unit では, 2050cps の $100 \mathrm{db}$ より $65 \mathrm{db}$ まで, $3000 \mathrm{cps}$ の $95 \mathrm{db}$ から $55 \mathrm{db}$ まで, の 2 周波数 の観察のみに終つたが，闎值は 2050 cps で $76 \mathrm{db}$ であつた。音刺战は $540 \mathrm{msec}$ 間隔で与兄られた. 第 3 図 A, B, C, D, はすべて $2050 \mathrm{cps}, 96$ $\mathrm{db}$ の音刺㦸に対する同一 unit か ら記録された反応を時間経過に従つ て示した. 第 3 因 A は全 15 個の音 刺战中第 1 の刺战に対する反応で， 著明な反応を示した． 図 B の反応 は図 A の刺战の $1620 \mathrm{msec}$ 後に与 之られた第 4 の音刺战に対寸る反応 であって, 反応放電量㤌非常に少 、㘠には示さなかつたが，図A と因 $\mathrm{B}$ との反沁の間に 2 回刺战加 与えられており，反応山中等度で， 图 C の反応之同程度であつた，図 C に示した反応は図 B の刺战 後 $1080 \mathrm{msec}$. 第 6 の刺战に対与る反応 である. 図 D の反応は図 C の反 応の $540 \mathrm{msec}$ 後, 第 7 の刺㦸汇刘 する反応であるが，図 A の反応と 同程度の区応にもどつた，その後も

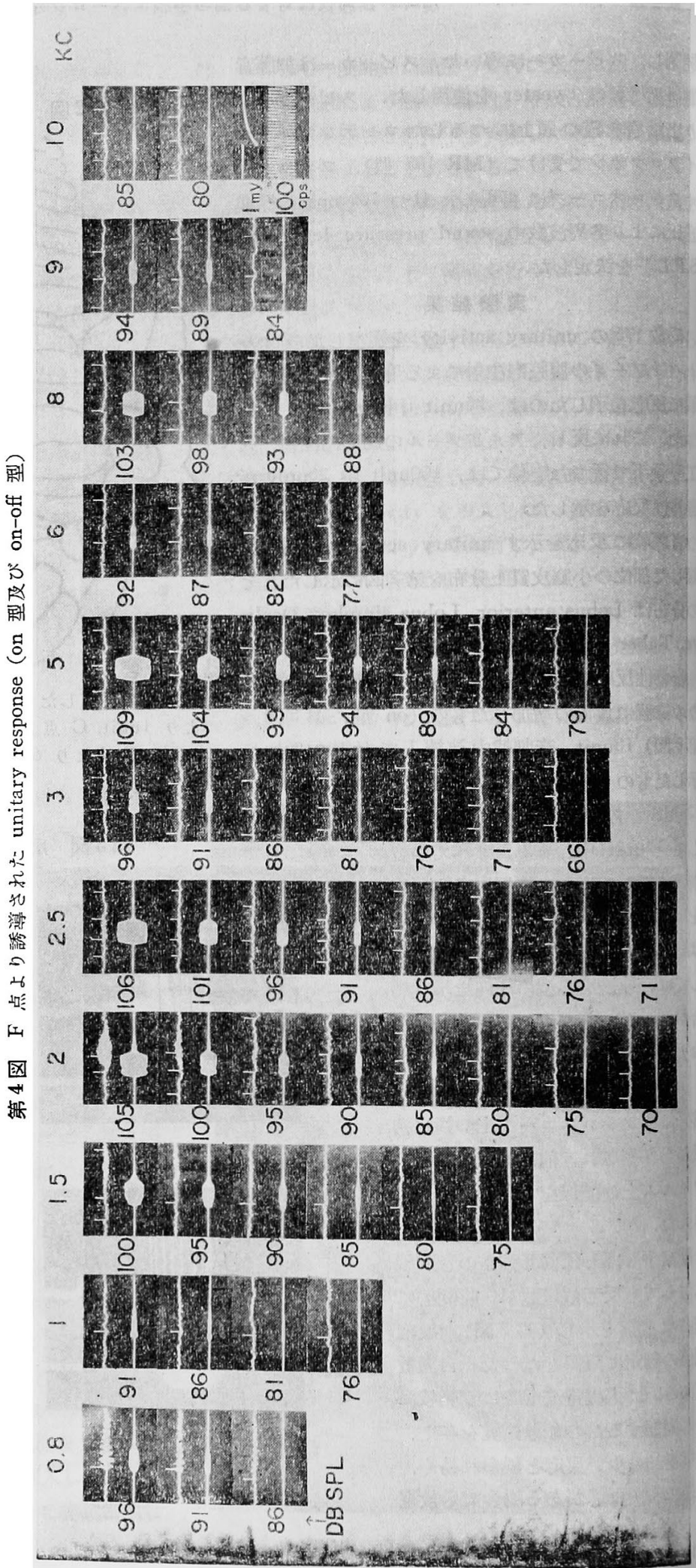


2 3 秒程度の周期で, 上記の如き反応の動摇が絽返さ れた。

第 4 図と第 5 図は $\mathrm{F}$ 点 (第 2 図)より誘道された unitary response の記録である. 第 4 図は spike discharge の写真記録である. 第 5 図は 10 回の刺㦸に迋す る反応を dot pattern とヒストグラムで表わしたもの
で, $1000 ， 2000 ， 2500 ， 5000 ， 8000 \mathrm{cps}$ の5 周波数の分を 示した，個々の記録は与えられた刺㦸音压に従つてヒス トグラムの基線を縦軸の $\mathrm{db} \mathrm{S} \cdot \mathrm{P} \cdot \mathrm{L} \cdot$ の該当目盛比含せ てある。

第5図に示したヒストグラムからこの unit の反応閔 値を判定し，応答野を調べた，第6图にその応答野を示

第 5 图第 4 因に示した response の dot pattern 及びヒストグラム

1

2

2.5
8 $\mathrm{KC}$
$110-$

$105-$

$100-$

95-.

85-

80-
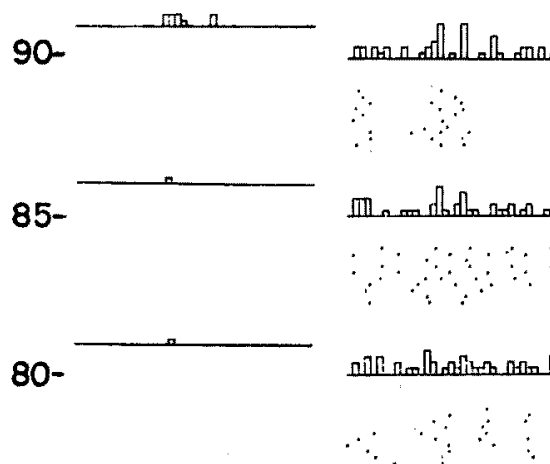

75 .

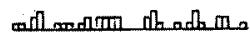

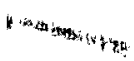

$70-$

DB SPL

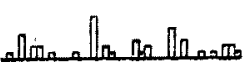

\section{$80 \mathrm{msec}$ Tone}

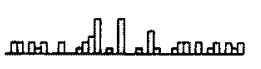<smiles>C#CC1[C+]#C[Si]1</smiles>

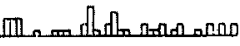

$\therefore \therefore \therefore \because \because \because$

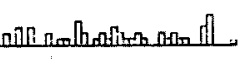
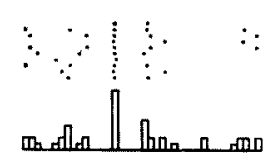

1. Cin

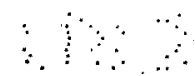

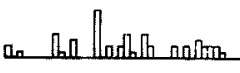

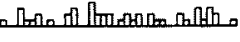

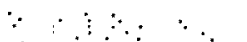

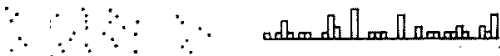

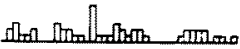

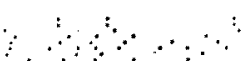

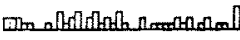

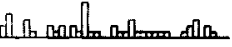

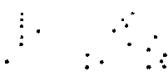
$\therefore \therefore \therefore$

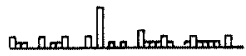

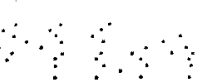

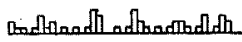

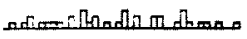

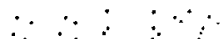

$\therefore \quad: \because: \because$

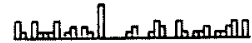

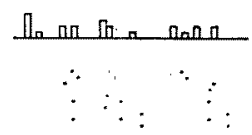

an thallothom dil tho

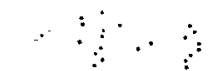

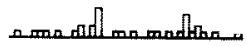

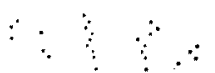

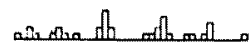

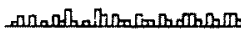

allow oflo nato nom 
した. 縱軸に $\mathrm{db} S \cdot P \cdot L ・$ 横軸に周波数をとつてある.

第 5 図に示した如く，1000 cps での反応は他の周波数

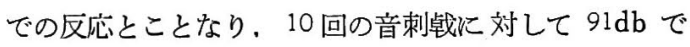
7 回, $81 \mathrm{db}, 76 \mathrm{db}$ では, 10 回刺㦸で夫々 1 ケの spike しか見られなかつた、これ等の spike はいずれも on 反応の位置にあつたが，91db を閾値とした．2000cps では $105 \mathrm{db}$ で明膫な on 反応があり，続いて抑制があ り, やや不明瞭な off 反応を示している. $100 \mathrm{db} て ゙ は$ off 反応は消失し, on 反応も $105 \mathrm{db}$ に比し僅か汇不明 瞭となつている． $85 \mathrm{db}$ が䦪值で， $80 \mathrm{db} ， 75 \mathrm{db}$ では自 発放電が見られるのみである.しかし，ょり弱刺钱の $70 \mathrm{db}$ で再びかなり明瞭な on 反応を示した。 $2500 \mathrm{cps}$ の間値は $91 \mathrm{db} て ゙, 76 \mathrm{db}, 71 \mathrm{db}$ で再び僅か沈応して いるかの如くである５000cps の最強音 $109 \mathrm{db}$ では殆 ど反応を示さず，104db，89db では明膫な反応を示し， $84 \mathrm{db}$ では殆ど反応を示さず，76db で再びかなり明瞭 な反応を示している. 図には示さなかつたが，6000 cps では，いずれの強さの音でも反応を示さず，闒値は最強 音 $92 \mathrm{db}$ 以上と思われる. $7000 \mathrm{cps}$ では同様に $95 \mathrm{db}$ 以 上の閔値と考兄られた． $8000 \mathrm{cps}$ では $103 \mathrm{db}$ で多少反 応する攧向を示し，97db では殆ど反応していないが， $93 \mathrm{db} ８ 8 \mathrm{db}$ では再びかなり明瞭な反応を示した． 8000 cps の最強音が $103 \mathrm{db}$ であるため正確な闇值は分らな いが, 6000cps, 7000cps の間値が夫々，92db，95db 以 上であることや，2000 cps の反応の型式を参嘋にして， $103 \mathrm{db}$ を一応閵值と判定した.

第6 図の關値曲線の下部示した点は, 闒値下で再び 反心を誘起した刺㦸を plot したものである.

第 6 図第 4 図, 第 5図に示した response の応答野

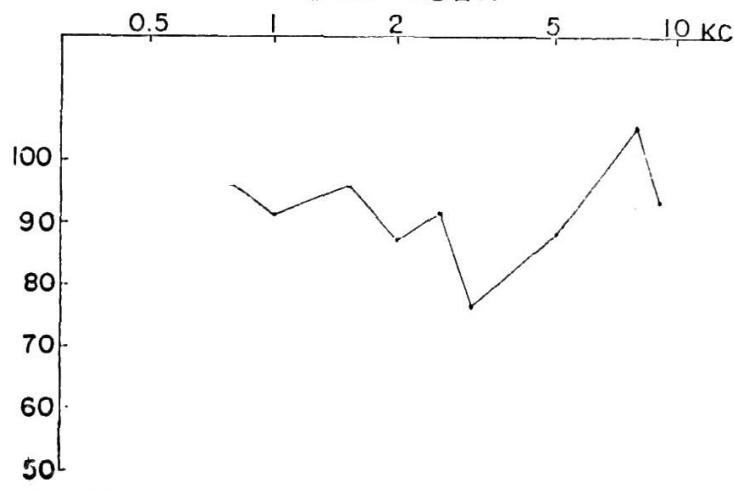

db.S.P.L.

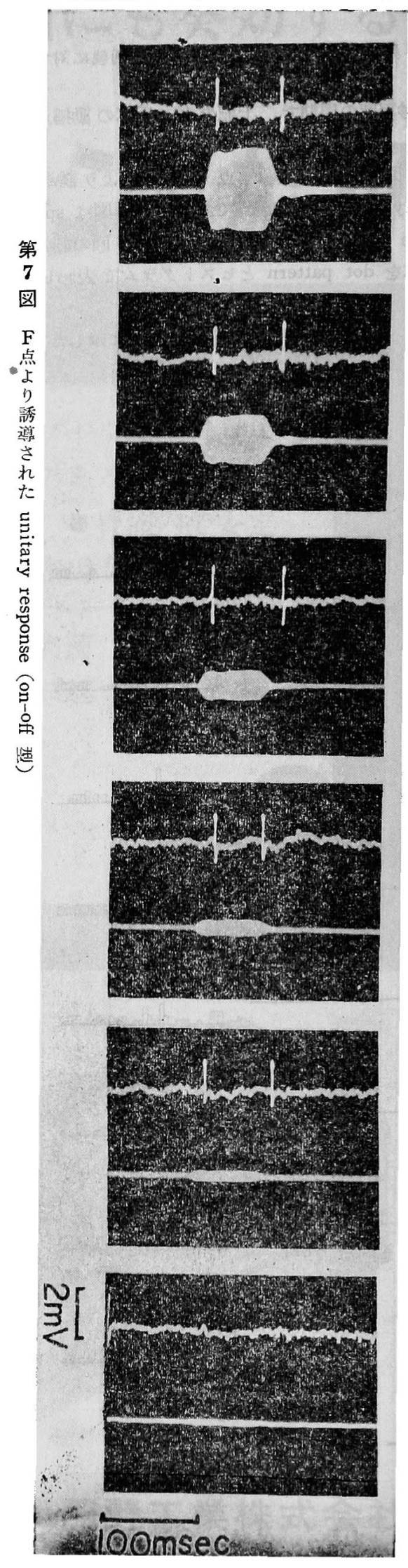


第 5 図の dot pattern に見られる 如 く, $2000 \mathrm{cps}, 105 \mathrm{db}$ 及び $5000 \mathrm{cps}, 103$ $\mathrm{db}$ では on〜off 型の反応を示したが， 他の音の強さでは off 反応は殆ど認めら れなかつた、しかし全周波数につき反応 を観察 した後, 再び $2000 \mathrm{cps}$ の反応を 観察したところ，第7 図に示した如くか なり 明瞭な on〜off 型反応を示した. これも反応動摇の一現象と考えられる. 前述の如き 2 3 秒の周期で起る 動摇の 外にこのような長い周期の動摇も教偲し なければならない，なお，閾值，泚時に は変動は認められなかつた。

第8図にD点より得られた unitary response を示した. 第9 図はこの unit の反応の dot pattern とヒストグラム である. 自発放電が多少見られ，間値の 判定はヒストグラムによつた. $2350 \mathrm{cps}$, $95 \mathrm{db}$ 及び $5600 \mathrm{cps}$, $95 \mathrm{db}$ で on 反応の みならず，時に off 反応も示したが， 第9図に示す如く, 全体としては on 型 であつた. $7000 \mathrm{cps}, 82 \mathrm{db}$ で反応はやや 不明膫で, 閥値は $82 \mathrm{db}$ 付近と思われる が，77db で再び明瞭な反応を示した. $3300 \mathrm{cps}, 74 \mathrm{db}$ 及び $2350 \mathrm{cps}, 81 \mathrm{db}$ でな お反応しているが，反応がやや不明暸に なつているので, 一応この付近を閶値と 判定した. かくして得られた応答野を第 10 図に示した。閖値曲線は非常に平坦 な折線で示され，特徽振動数は明示でき なかつた。

第11 図は $G$ 点より得られた unitary response の dot pattern である. 閾值 附近では $5 \mathrm{db}$ ステップで反応を調べた が，十分強い音刺㦸では $10 \mathrm{db}$ 毎に記録 した.この unit は音刺㦸中, 連続的反 応を示した，音の強さが弱くなるにつ れ, 反応放電数は減少し橴時も延辰与る 傾向が钼察された，例光ば $3000 \mathrm{cps} の$ $118 \mathrm{db}, 108 \mathrm{db}$ では潜時は平均 $12 \mathrm{msec}$ で变化はなく, 反応放電量も殆ど変化な からた、しかし93db では放電量がやや 減少している，㴧祂はまだ殆ど変化して

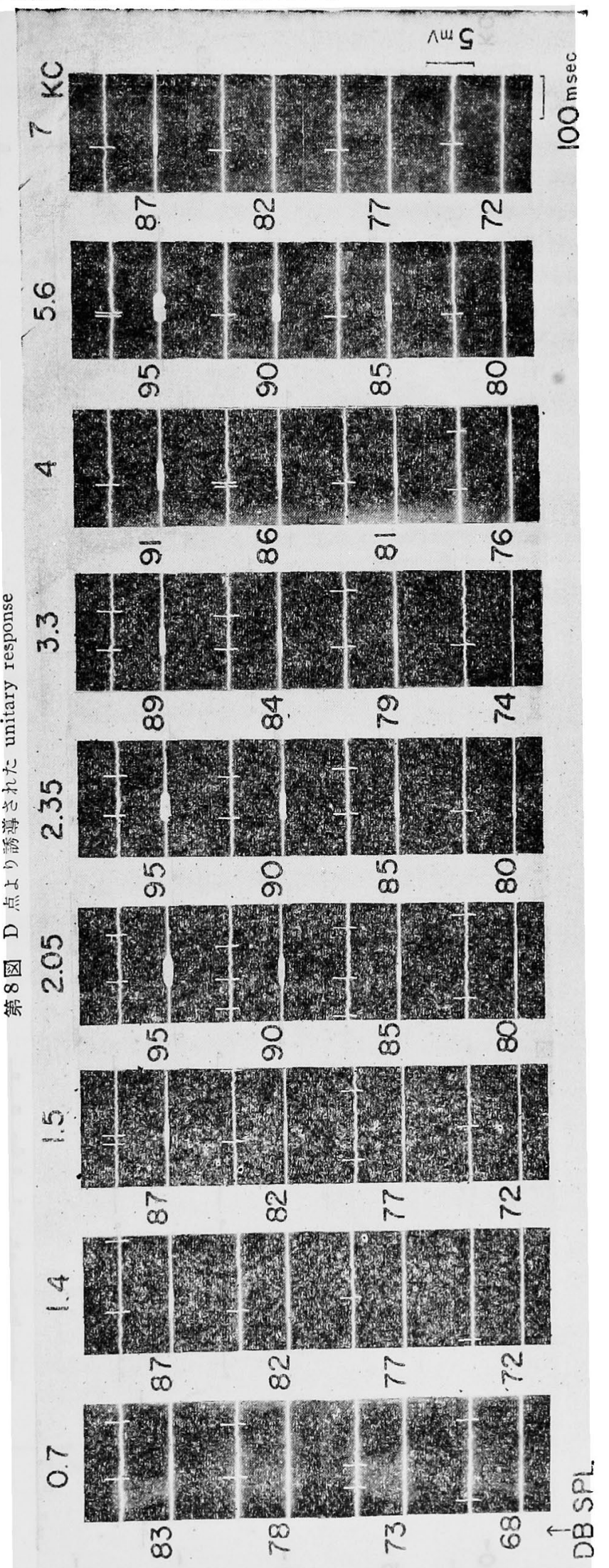




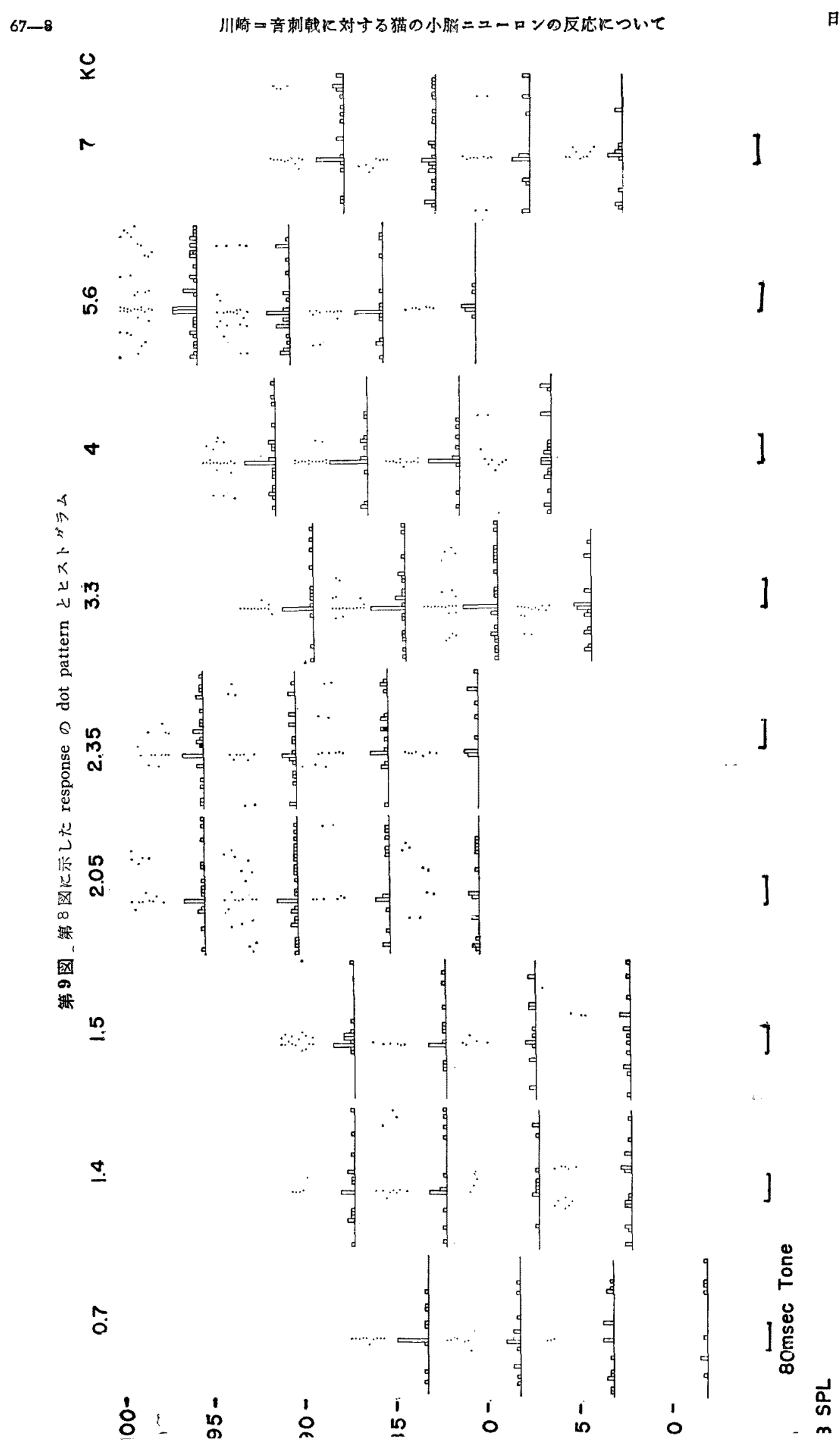


いかい $88 \mathrm{db}$ では潜時も平均約 $15 \mathrm{msec}$ とやや延長し

第 10 图 第 8 図・第 9 図に示した response 9 応答野

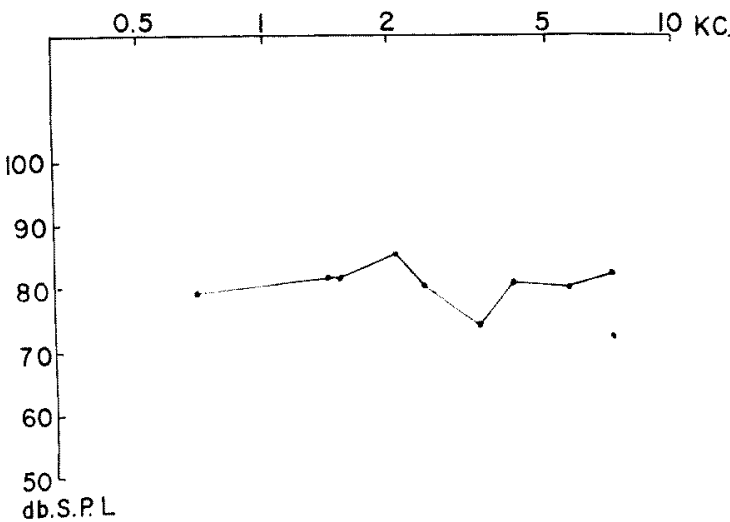

た．78db でも反広はある如くに見党るが，非常に不明

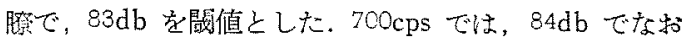
反応を示して招り，84db 以下の反応を記録しなか つたので閶值を判定できなかつた１000cps でも同 様に䦪值を判定できなかつた，5000cps，64db 虫闒 值下の 刺㥂であるか゚，再び明膫な反応が認められ た.

以上この unit を全般的に見ると，闒値は低周波 数域で低く，高凬波数域で高い傾向を示した。しか 乙反応放電量の藷明な增加は高周波数域に泌集して

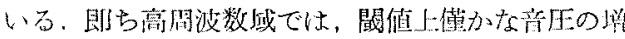

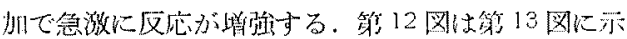
した unitary response の閶值曲線である。

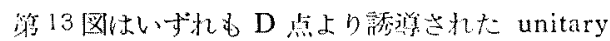

第 $\mathbf{1 1}$ 图 $G$ 点より唀整された response の dot pattern

0.7

$$
1
$$

1.5

2

$120-$

$115-$

$110-$

$105-$

मn:

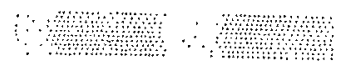

100-

95-

$90-$

85

80-

$75-$

70-

$65-$

$77 \mathrm{msec}$ Tone
5

8

$10 \mathrm{KC}$ 
第 12 图 第11 図に示した response の応答野

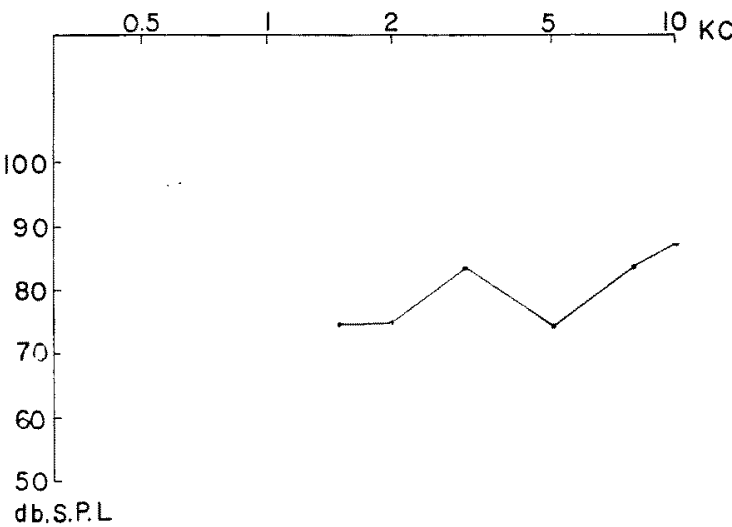

第13图 锶察のみにより汹定さ秃た応答野 (D点)

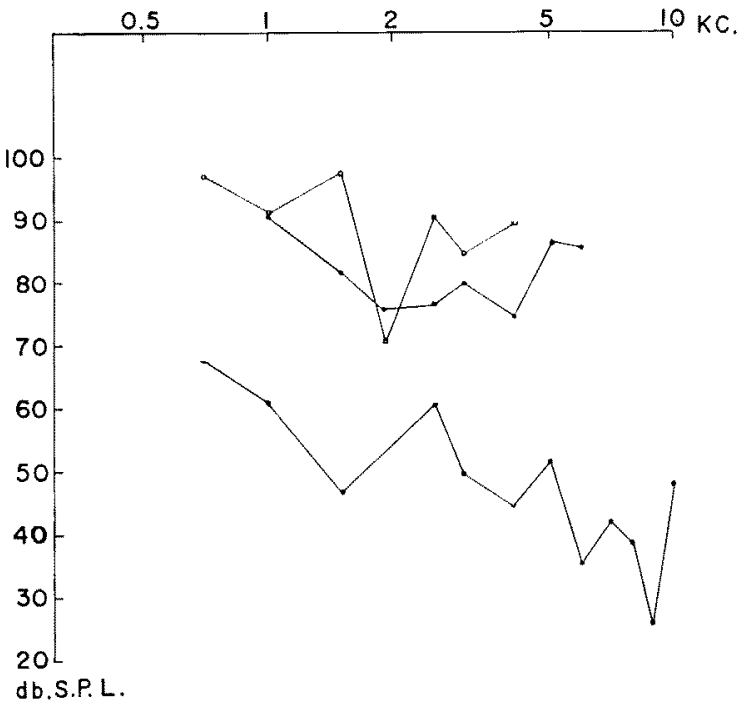

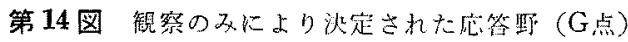

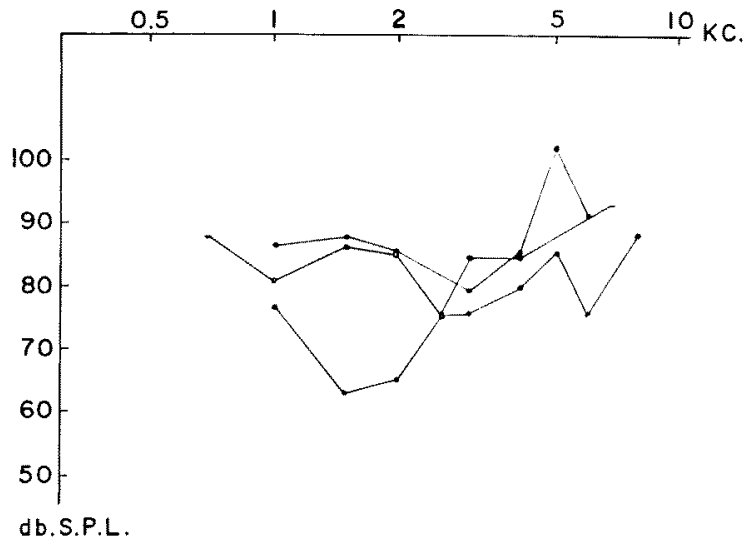

response の応答野で，オッシロスコーブ上の観察 のみにより得られたものである.3つの unitの

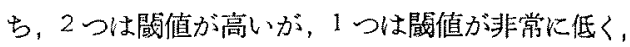
$9000 \mathrm{cps}$ で $28 \mathrm{db}$ に反応した. この unit $の 8000$ cps については，フイルム上の記録も得たので、観 察のみで判定した閶值と比較すると, 約 $15 \mathrm{db}>1$ ルム記録に上る判定閾值の方が高い値を示した。 こで的12罒の応答野については，観察のみにより 調ハた応管野とフイルム記録に上石庆管野とが得ら れているので比恔した結果，この場命、，フイルム

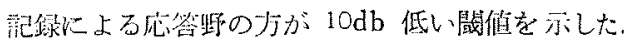
この恙異が閥值の長周期動摇によるためか，あるい は钼案の誤差によるるのかは不明である. 全く誤差 に上るものとすれば士10db 程度の测定誤差を考慮 ナ゙べきである。

第 14 図は D 点上り得ら玌た unitary response の匛然野を 3 示し太。

以上の応答野の他に，国には示さなかつたが2000 $\operatorname{cps}$ 加 $7000 \mathrm{cps}$ 迄の 5 周波数について， G 点 り記録した unit があるが，閾值は 60〜 66dbで， 第13図・第14図に示したものと大差はなからた。

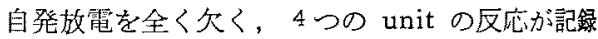
されているが，応答野を調べ得なかつた。文音刺幟 により放電数を減ずる unit は観察できなからた。

\section{考按}

小脳の渎性反応については，古くは Dow (1939) 3) が馀脳猫で内耳神経を刺战すると，藮小結節，小 舌虫金部，室頂核に電位变化が和こることを㓋だ。 Snider 及び Stowell (1944) 10) は猫で岵性及び視 性刺剚により Lobus simplex, Tuber vermis 誘発電位を諨録した，Bonnet 及び Bremer (1954) 1)はこれを確梕し，小脳に和子る聴性刺幟による反 伈と他の感覚による反応との間に summation があ ると述べている。 Whitlock (1952) 12)によれば, 鳥類の小兴の Folium VIc (Caudal declive), Folium VII (Folium tuber vermis lobue) $k$ Folium VIII (Pyramis) は click 音刘して4 〜10msec の潜㭙をもつて反応するとい5. Snider と Eldred (1952) 11) は, 猿で大細の聴領を電気的 に刺㦸し, Lobus simplex と Folia の外内側傜 発電位を認めた。 Misrahy 他 (1961) ${ }^{9}$ は, 小脳か ら大脳聴領の電気刺拨及び音刺㦸による誘発電位を 夫ィ記録し，両者の潜時及び音刺㦸による誘発電位 
が2つの山を示すことから，小脳への聴性線維連絡は 大脳の 皮質㯖領を 経るものと，下丘からくるものとの 2 種を想定して，Snider の仮設を支持している．志村 (1955) ${ }^{18)}$ b音響性亚に，大脳聴領の電気刺㦸炕よる誘 発電位から，小脳に至る 2 つの経路を確認している。

かくの如く小脳の聴性反応については，多くの研究が あるが, unitary response についての研究は Bremer 及び Gernandt (1954)2)，垭田 (1957)14) の論文を見る のみである. Bremer 及び Gernandt は比較的太い電 極 (尖端口径 10 数 $\mu$ ) で, click 音を用い誘発電位の逆 転層を調べるとともに， unitary response と一致する 誘発電位の位相を調べ誘発電位の source の推定の一助 としている. 即ら unitary response に関しては一疬記

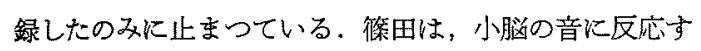
る unitary response を大別して，(1) 音刺㦸により故 電数の增加を示寸もの，(2) 咅刺㦸により放電数の減少 を示するの，の両者を確認しだが，著者の観察では音 刺㦸により放電数の減少を示す unit は確認できなか た. その反面、筥田の確認できなかつた on 型の反応を 示す unitを観察した。この相違は, 微田が tone pip の音量不足から連続音のみを刺战に使用したのに対し， 著者は十分なる音量の tone pip を使用したための美で あろう.

大脳聴領から得られる unitary response は Katsuki 他 (1959)6) に上れば，大部分が on 型，あるいは onoff 型, off 型を示すという.小脳では著者が観察し得 た unitary response の範围では, on 型が約半数, 連 続反応型が半数であつた．小脳でも，大脳で見られる反 応型はすべて認められたが，大脳化比して連䋁反応型が 非常に多く，更に全体として on 型を示严ものでも，例 えば第 5 図の $1000 \mathrm{cps} 91 \mathrm{db}$ ，第9図の $1500 \mathrm{cps} 87 \mathrm{db}$ に示した如く，一部では連続反応型を示した。

篠田の钼察によると，小脳の聴性反応を示す unitary activity には麻酔の影響なしといらが，著者は麻酔の影 響を確詔した。

第 3 図に示した如く，反応量が2〜3 秒の周期で 動摇 する unit が認められたが，他の unit 殆どこのよう な動摇を示した． 2 乃至 10 秒の範团で, その周期は稙合 であつたが，unit の性質の盖か，あるいは他の条件の 差によるものかは不明である，下丘以下のレベルの聴覚 経路ニューロンでは，この上うな動摇は著者等の絽䨐で も, 他の研究者の報告でも認められていない上記応 の動摇は他のニニーロンからの抑制あるいは促進が関与
して起つたものであろう．

更に Galambos (1944)4) は聴神経で, Greenwood 及び Maruyama (1963)5) は螖牛神経 背側核で，音刺 㦸に対する抑制野を観察して和り，Katsuki 等 (1962) 7) は大脑ニニーロンで，㕕い応答野と狭い応管野とを識 別し，狭い応答野の周辺に抑制を認めている。藷者の観 察でも，この抑制を思わせる所見が第6 図・第 9 図に示 されている，即方刺㦸を弱くなると一度反応が消失し， 更に刺㦸老弱くすると再び反応が見られる，反応の現わ れない強さの音刺战では一見抑制が起つているかのよう に見える。しかし dot pattern や，ヒストグラムで明 瞭な如く、自発放電には変化が見られず, 従つて抑制で はなく，単に反応がない所見である．即ち，当該 unit 化 impulse を送る presynaptic neuron が，ある強さ の音刺战により抑制されるためにこの unit に impulse を送り得ないので，反応を示さないるのと思われる。

小脳ニニーロンの反応闌値が 高いといら所見に就い て, 條田は小脳に入る前で閶值の高い特殊なニユーロン を介する結果であ万らと述べているが，恐らく小脳䎲入 る前の核に存在すると思わ机るニューロン（小敛二ユー ロソの presynaptic neuron) が抑制を受けて，結果的 には篠田の云う間値の高いシナッブスに相当するすのを 構成しているのであるら。

かくの如く，小脳ニューロンの闇値は明らかに高い が，第 13 図に示した如く，1つたけ非常䔽值の低い unit が観察された。これがいかなる意味をるつかは不 明である。

Katsuki 他 (1962) 7) が指摘した大膇の聴領の厇い応 答野と，著者の観察した小脳の応管野に類似している面

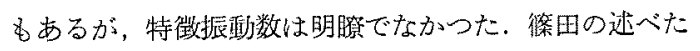
如く，音の弁別には関係ないと思的れる。

\section{総括}

著者は猫を用い，小脳の音響性刺㦸に対応する unitary response について観察し，次の如き結果を得た。

（1）総数 175 unit 観察中, オルトハンソーダの碄醇 下では75unit 中2unit, タラーレを使用した奏験では 100unit 中 23unit が音響性刺皒に刘して反庆を示した。

（2）反応型としては，音刺战に対して，主として on の位置のみに反応する型と, 刺短中連続的に反心する型 老観察した。

（3）音響性反心を示す unitary response には2〜10 秒の周期で起る動摇が推察された。

(4) Lobus anterior, Lobus simplex, Declive, 


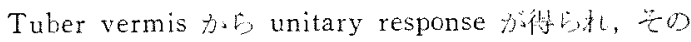

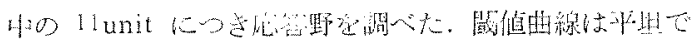

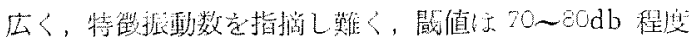
で高から犬. Declive 上り得られた lunit た纣 $28 \mathrm{db}$

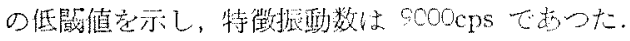

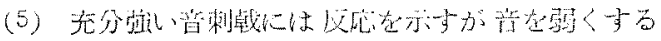

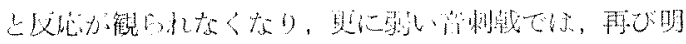

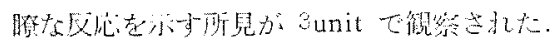

\section{文献}

1) Bonnet, V. and Bremer, F.; Auditory responses of the cerebellum. J. Physiol.. 1951, 114:548.

2) Bremer, F. and Gernandt, B.E.: A micro-electrode analysis of the accustic response and the strychnine convulsive patterns of the cerebellum. Acta Physiol. Scand. 1954, 30: 100 136. 3) Dow, R.S.: Cerebellar action potentials in response to stimulation of various afferent connection. J. Neurophysiol.. 1939, 2:543, 555. 4) Galambos, R.: Activity in single auditory nerve fibers. J. Neurophysiol., 1944, 7:287 303. 5) Greenwood. D.D. and Maruyama, N.: Excitatory and inhibitory response areas of units in cochlear complex of cat. Fed. Proc., 1963, 22:2. 6) Katsuki, Y., Watanabe, T., and Maruyama, N.: Activity of auditory neurons in upper lcvels of brain of cat. J. Neurophysiol.. 1959, 22:343 359. 7) Katsuki, Y., Suga, N., and Kanno, Y.: Neural mechanism of the peripheral and central auditory system in monkeys.
J. Acoust. Societ. Amer., 1962, 34: 1396 1410. Maruyama, N., Kagitomi, T., Shinoda, H., Higuchi A., Kanno, Y., and Morimoto, M.: Electric response to sound stimulation from the cerebellum in cat. Acts med. biol., 1957, 4: 317 324. 9) Misrahy, G.A, Spradley, J.F., Beran, A.U., and Garwood, V.P. Acoustic cerebellar pathways in cats. J. Neuroph ysiol., 1961, 24: 159 166. 10) Snider, R.S. and Storcell, A.: Receiving areas of tactile, auditor. and visual systems in the cerebellum. J. Neuroph. ysiol., 1944, 7:331 358. 11) Snider, R.S. and Eldred, E: Cerebro-cerebellar relationships in the monkey. J. Neurophysiol., 1952, 15:27 40.

Whitlock, D.C.: A neurohistological and neurophy siological study of afferent fiber tracts and receptive areas of the avian cerebellum. J. Comp. Neurol.,"

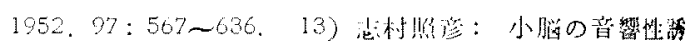

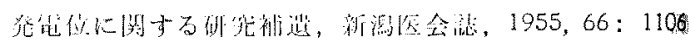

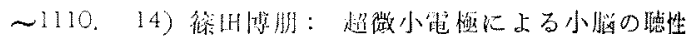

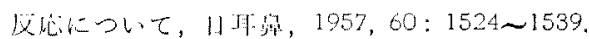

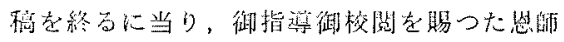
蒜本正紀教授，丸山直滋助教授に深进なる謝意

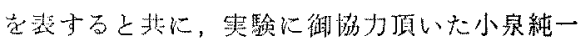

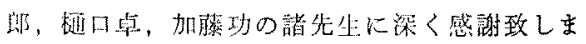
斗

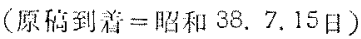

